\title{
Expression of Bcl-2 marker in premalignant lesions of cervical cancer
}

\author{
Shreedevi Kamaraddi ${ }^{1 *}$, Ashwini Nayak U. $^{2}$, Shridhar Honnappa ${ }^{3}$, Asha Swarup ${ }^{4}$
}

\author{
${ }^{1}$ M. S. Ramaiah Medical College, Bengaluru, Karnataka, India \\ ${ }^{2}$ Associate Professor, Department of Obstetrics \& Gynaecology, M. S. Ramaiah Medical College, Bengaluru, \\ Karnataka, India \\ ${ }^{3}$ Associate Professor Department of Pathology, M. S. Ramaiah Medical College, Bengaluru, Karnataka, India \\ ${ }^{4}$ Professor and Head of Department of OBG, M. S. Ramaiah medical College, Bangalore, Karnataka, India
}

Received: 26 February 2016

Accepted: 02 March 2016

\section{*Correspondence:}

Shreedevi Kamaraddi,

E-mail: shree.kamaraddi@gmail.com

Copyright: (C) the author(s), publisher and licensee Medip Academy. This is an open-access article distributed under the terms of the Creative Commons Attribution Non-Commercial License, which permits unrestricted non-commercial use, distribution, and reproduction in any medium, provided the original work is properly cited.

\begin{abstract}
Background: Cervical cancer is one of the most common gynecological cancers in women of developing countries. HPV DNA testing is preferred cervical screening method for woman 30-65 years old as HPV is the proved causative agent of cervical carcinoma. Due to the high costs involved in doing HPV DNA test there is a need for a biomarker such as Bcl-2 which can indicate the initiation of carcinogenic process of HPV infection and thus can be used to identify those woman who will need more surveillance.

Methods: Specimens of cervical biopsy retrieved from incident cases for routine histopathological evaluation from the Department of Obstetrics and gynecology, M.S. Ramaiah hospital, Bangalore, India from March 2013 to September 2015 formed the source of data for the study.

Results: In this study total of 46 cases were studied which included 9 cases of CIN-1, 8 cases of CIN-2, 7 cases of CIN-3, 12 cases of squamous cell carcinoma and 10 cases of on specific cervicitis. Higher number of malignant lesions (75\%) expressed Bcl-2 positivity as compared to premalignant lesions $(62.5 \%)$. In case of CIN lesions, Bcl-2 positivity increased as the grade increased (CIN-1- 55.56\%; CIN-2 - 62.5\%; CIN-3 -71.43\%).

Conclusions: Bcl-2 which is an intracellular membrane protein which prevents apoptotic cell death can be used as a biomarker to know the severity of the CIN lesion and hence help in identifying the high risk CIN lesions which need further surveillance and treatment.
\end{abstract}

Keywords: Cervical cancer, Screening, Biomarker

\section{INTRODUCTION}

Worldwide, cervical cancer is both the fourth most common cause of cancer and the fourth most common cause of death from cancer in woman. Current estimates indicate that every year 122844 are diagnosed with carcinoma cervix and 67477 die from the disease. ${ }^{1}$ In hospital based cancer registries cancer of the cervix is leading site in Bangalore and Chennai (Nandakumar et al). ${ }^{2}$ Its high mortality exemplifies health equity with high rates in developing countries like India which has a burden of carcinoma cervix accounting for nearly $1 / 3 \mathrm{rd}$ of global cervical cancer. ${ }^{3}$ "Cervical cancer kills 1 Indian woman every 7 minutes". ${ }^{3}$ Human papilloma virus (HPV) infection appears to be involved in almost all the cases. Cervical cancer is easily preventable by efficient screening.

Cervical cancer is most common in woman $>30$ years old, therefore co-testing using the combination of pap cytology plus HPV DNA testing is preferred cervical screening method for woman 30-65 years old. Carcinogenicity of different types of HPV for cervix is partly related to expression of two early genes, E6, E7 
oncogenes. E6 and E7 oncoproteins interfere with the functioning of suppressor protein p53 and pRB respectively which are apoptotic proteins.

The major test for detection of carcinogenic HPV DNA is hybridization with signal amplification using PCR. HPV testing being costlier, needs sophisticated equipment; its incorporation is possible only in wealthy countries like U.S. However cervical cancer is more commonly seen in developing countries like India where it is responsible for $90 \%$ deaths. $^{3}$

The biomarkers of cell proliferation and apoptosis like p53, bcl-2, cytokeratin, cyclin E, p16 etc. indicate the initiation of carcinogenic process of HPV infection, thus can be used to identify those woman who will need more surveillance.

Bcl-2 is an intracellular membrane protein which prevents apoptotic cell death. Overexpression of bcl-2 can block p53 mediated G1 arrest. ${ }^{4} \mathrm{Bcl}-2$ overexpression is present in premalignant and malignant lesions of cervix. It has been suggested that alteration of bcl-2 expression is a relatively early event in cervical tumorigenesis. ${ }^{5} \mathrm{Bcl}-2$ positivity has also been shown to confer a better 5 year survival rate and prognosis. ${ }^{5}$

The expression of $\mathrm{Bcl}-2$ was found to increase in direct relation to the grade of CIN. ${ }^{6}$ It is found that (a) the presence of bcl-2 protein strongly associated with development of invasive cervical disease. (b) The pattern may be useful in identifying woman at increased risk for invasion and thus the requirement of immediate and aggressive treatment. ${ }^{7}$

The present study was done to evaluate the expression of bcl-2 in premalignant and malignant lesions of uterine cervix by immunohistochemistry. The bcl-2 expression will be correlated with the clinical stage and histologic grade of the lesion.

\section{Objectives}

To evaluate the expression of $\mathrm{Bcl}-2$ in premalignant lesions of uterine cervix.

\section{METHODS}

\section{Study sample}

Specimens of cervical biopsy retrieved from incident cases for routine histopathological evaluation from the dept. of Obstetrics and gynaecology, M. S. Ramaiah hospital, Bangalore, India from March 2013 to September 2015 formed the source of data for the study.

\section{Study design}

Cross sectional study.

\section{Sample size: 46}

\section{Rationale for sample size}

Shukla et al study has observed that $84.21 \%$ of CIN expressed Bcl-2. In the present study expecting similar results with $13 \%$ of relative precision and $95 \%$ confidence level in the results, the study requires minimum of 46 subjects.

\section{Study period}

Archival cervical biopsy specimens over one and a half years were studied.

\section{Inclusion criteria}

1. Cervical biopsy specimens received from incident cases for routine histopathological evaluation.

2. Biopsies from hysterectomy done for gynaecological conditions

\section{Exclusion criteria}

1. Inadequate biopsy, ulcerated and necrotic tissue.

2. Biopsies of secondary carcinomas of the cervix.

\section{Study method}

The study comprised of 46 cases. The detailed clinical history and results of relevant investigations done were collected from the patients' case files. For retrospective cervical biopsy cases the histopathology reports, slides and paraffin blocks were retrieved from the archives. $4 \mu \mathrm{m}$ sections were cut from paraffin block of cervical biopsy tissue and taken on a glass slide coated with adhesive (silane) for immunohistochemistry (IHC) to detect bcl-2 expression.

The technique for IHC included antigen retrieval in citrate buffer in a microwave oven, blocking endogenous peroxidase with $3 \%$ hydrogen peroxide, incubating with primary mouse monoclonal antibody against bcl-2 protein linking with rabbit anti mouse secondary antibody (biogenex), enzyme labelling with streptavidin-biotin and counterstaining with haematoxylin. Positive and negative controls were run with each batch of slides. The $\mathrm{H}$ and $\mathrm{E}$ stained slides were studied for the histopathological changes and the categorization of the cervical lesion. The immunostained slides were examined for cytoplasmic staining of bcl-2. In each case, the proportion of positive staining cells (expressed as percentage) and the average intensity of staining (expressed as $0,1,2$ or 3 ) were evaluated. A case was taken as positive if more than $10 \%$ cells showed cytoplasmic reactivity. ${ }^{8}$ Score representing the sum of intensity and distribution of staining in fields representing dysplastic epithelium and respective sub epithelial stroma was attributed to each case. Staining intensity (epithelium and stroma) as following; 0 - no 
staining; 1 - weak staining; 2 - moderate staining; 3 intense staining.

Correlation between the clinical findings, Pap smear report, routine histopathological biopsy reports and the immunohistochemical analysis were made to improve the diagnostic efficacy of cervical squamous epithelial lesions.

\section{Statistical analysis}

Descriptive statistics of bcl-2 analysed and explained in percentage.

\section{Implication}

1. HPV testing being expensive, there is a need for the simpler and more economical test in developing countries.

2. Reduce the disease burden with marked reduction in premalignant lesions developing into advanced stages of cancer by early detection.

3. Reduce the need for invasive procedure, unnecessary hospitalization and economic burden with early detection and provide better surveillance.

\section{RESULTS}

In this study total of 46 cases were studied which included 9 cases of CIN-1, 8 cases of CIN-2, 7 cases of CIN-3, 12 cases of squamous cell carcinoma and 10 cases of on specific cervicitis.

Patient aged in the range of 23 years to 80 years were studied with mean age being $48.56(\mathrm{~S} . \mathrm{D}=14.2)$ years. We observed that pre-malignant patients showed white discharge per vagina as common symptom compared to malignant where bleeding per vagina was more frequent symptom. In cases of Squamous cell carcinoma different stages were noted which are - $2 b, 3 a, 3 b$ and different types of squamous cell carcinoma included large cell non keratinizing type, large cell keratinizing, small cell type.

Early age of marriage was found to be associated with carcinoma cervix as most of the patients with early marriage showed the lesion.

Carcinoma cervix patients showed high parity as compared to CIN patients and non-specific cervicitis patients.

Cytoplasmic immunostaining which was of two types, diffuse type and localized to basal layer. Higher number of malignant lesions (75\%) expressed Bcl-2 positivity as compared to premalignant lesions $(62.5 \%)$. In case of CIN lesions, BCL2 positivity increased as the grade increased (CIN-1- 55.56\%; CIN-2 - 62.5\%; CIN-3 $71.43 \%$ ) (Table 1) (Figure 1 to 6 ).
Table 1: Bcl-2 positivity in CIN and cervical cancer.

\begin{tabular}{|llll|l|}
\hline S.no & Lesions & Total & $\begin{array}{l}\text { Bcl-2 } \\
\text { positive }\end{array}$ & Percentage \\
\hline 1 & CIN & 24 & 15 & $62.5 \%$ \\
\hline 2 & CIN-1 & 9 & 5 & $55.56 \%$ \\
\hline 3 & CIN-2 & 8 & 5 & $62.5 \%$ \\
\hline 4 & CIN-3 & 7 & 5 & $71.43 \%$ \\
\hline 5 & SCC & 12 & 9 & $75 \%$ \\
\hline 6 & $\begin{array}{l}\text { Non sp } \\
\text { cervicitis }\end{array}$ & 10 & 0 & $0 \%$ \\
\hline
\end{tabular}

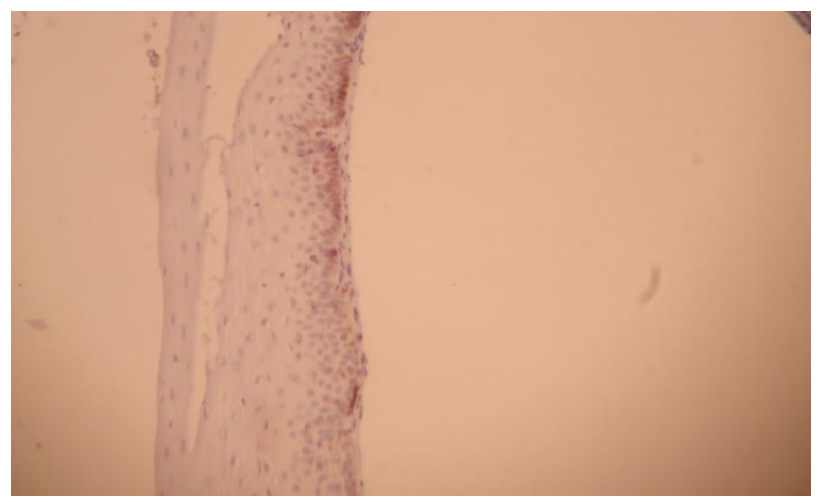

Figure 1: Brown cytoplasmic reactivity of bcl-2 in basal layer in a CIN1 lesion (lower power field image).

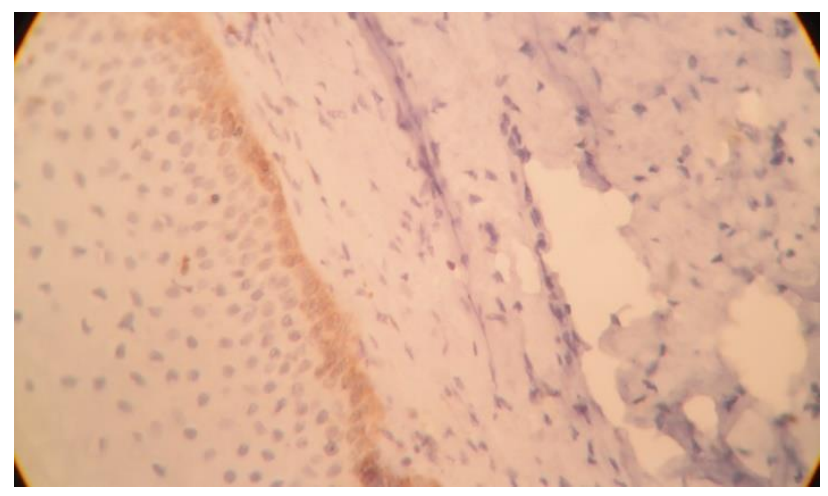

Figure 2: Brown cytoplasmic reactivity of bcl-2 in basal layer in a CIN1 lesion (high power field image).

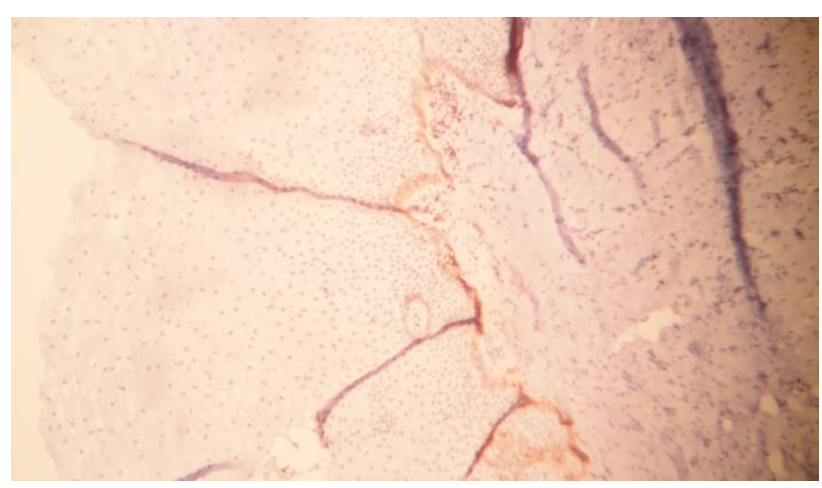

Figure 3: Cytoplasmic reactivity of bcl-2 in basal layer of CIN-2 lesion. 


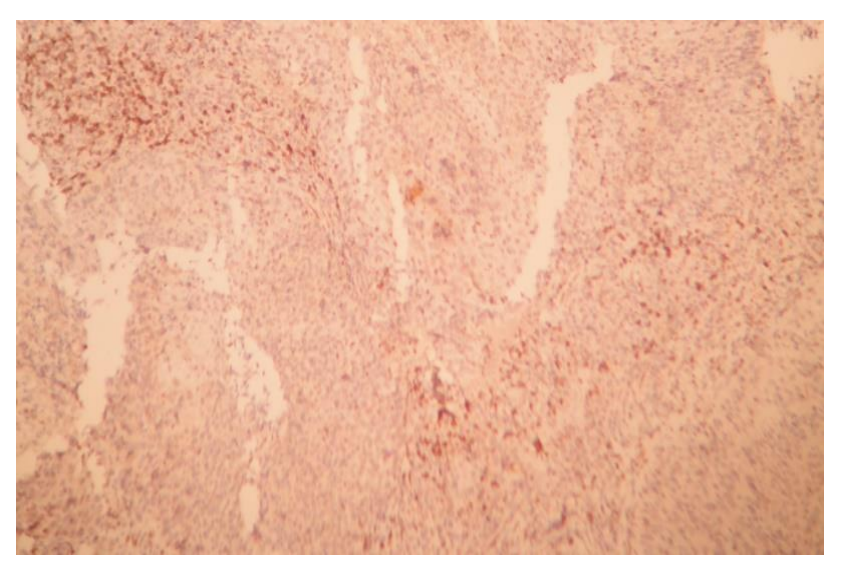

Figure 4: Diffuse cytoplasmic reactivity of bcl-2 in CIN-3 lesion.

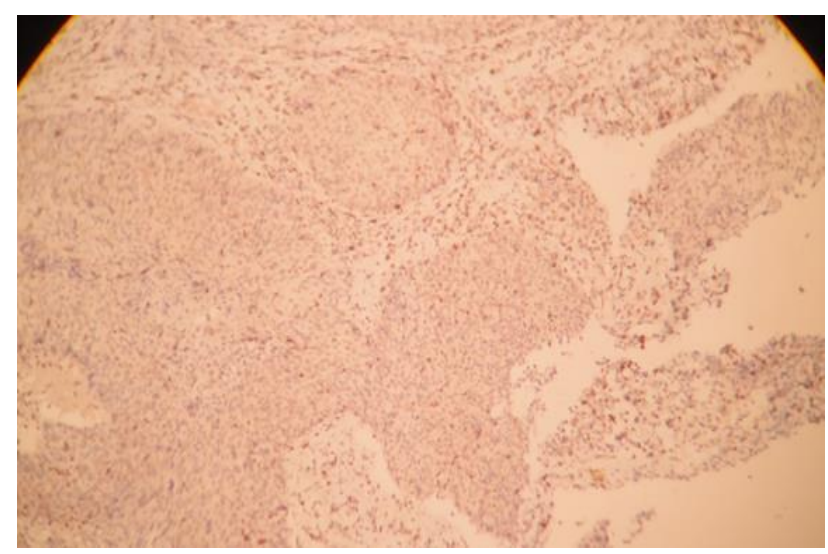

Figure 5: Diffuse cytoplasmic reactivity of bcl-2 in malignant lesion of uterine cervix (low power field image).

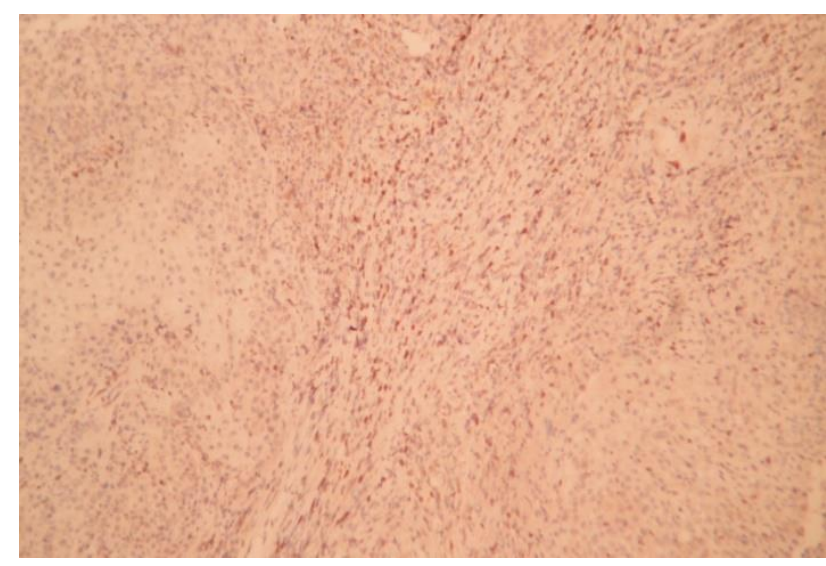

Figure 6: Diffuse cytoplasmic reactivity of bcl-2 in malignant lesion of uterine cervix (high power field image).

\section{DISCUSSION}

Worldwide cervical cancer is both $4^{\text {th }}$ most common cause of carcinoma and $4^{\text {th }}$ most common cause of death from carcinoma in women. Developing countries like India has burden of carcinoma cervix accounting nearly
$1 / 3^{\text {rd }}$ of global cervical cancer. Biomarkers of cell proliferation and apoptosis had been studied which indicate process of carcinogenesis process of HPV infection. Bcl-2 is a biomarker an intracellular membrane protein which inhibits apoptotic cell death. Bcl-2 over expression is present in pre-malignant and malignant lesions of cervical cancer. Limited numbers of studies available on bcl-2 expression are available.

This study was taken up to evaluate the expression of Bcl-2 $\mathrm{n}$ premalignant and malignant lesions of uterine cervix using immunohistochemistry and to correlate with clinical stage and other clinical features.

In the present study $\mathrm{Bcl}-2$ positivity increased as the grade increased (CIN-1- 55.56\%; CIN-2 - 62.5\%; CIN-3 $71.43 \%$ ) which is similar to most studies by Kurvinen $\mathrm{K}$ et al, Pillai MR et al, Brychtova $\mathrm{S}$ et al, Nair $\mathrm{P}$ et al, Grace et al which have also shown increasing expression of Bcl-2 with increasing grade of CIN., ${ }^{4,10,11,13}$ Conversely few others have shown decreased expression of BCL2 with increasing grade of CIN. ${ }^{6,8,12}$ Shukla et al being the recent study has shown reduced expression of Bcl-2 as CIN grade increased however it was not found to be significant. ${ }^{8}$

\section{CONCLUSION}

Bcl-2 which is an intracellular membrane protein which prevents apoptotic cell death can be used as a biomarker to know the severity of the CIN lesion and hence help in identifying the high risk CIN lesions which need further surveillance and treatment.

\section{Funding: No funding sources}

Conflict of interest: None declared

Ethical approval: The study was approved by the Institutional Ethics Committee

\section{REFERENCES}

1. Report-ICO Information Centre on HPV and Cancer. www.hpvcentre.net

2. Nandakumar A, Ramnath T, Chaturvedi M. The magnitude of cancer cervix in India Indian $\mathrm{J}$ Med Res. 2009;130:219-21.

3. Ferlay J, Shin HR, Bray F, Forman D, Mathers C, Parkin DM. Estimates of worldwide burden of cancer in 2008: Globocan. 2008.

4. Kurvinen K, Syrjänen K, Syrjänen S. p53 and bcl-2 proteins as prognostic markers in human papillomavirus-associated cervical lesions. J ClinOncol. 1996;14:2120-30.

5. Aletra C, Ravazoula P, Scopa C, Kounelis S, Sotiropoulou G, Kourounis G. Expression of bcl-2 and bax in cervical intraepithelial neoplasia and invasive squamous cell carcinoma of the uterine cervix. Eur J GynaecolOncol. 2000;21:494-8.

6. Dimitrakakis C, Kymionis G, Diakomanolis E, Papaspyrou I, Rodolakis A, Arzimanoglou I. The 
possible role of p53 and bcl-2 expression in cervical carcinomas and their premalignant lesions. Gynecol Oncol. 2000;77:129-36.

7. Pillai MR, Halabi S, McKalip A, Jayaprakash PG, Rajalekshmi TN, Nair MK et al. The presence of human papillomavirus-16/-18 E6, p53, and Bcl-2 protein in cervicovaginal smears from patients with invasive cervical cancer. Cancer Epidemiol Biomarkers Prev. 1996;5(5):329-35.

8. Shukla S, Dass J, Pujani M. p53 and bcl2 expression in malignant and premalignant lesions of uterine cervix and their correlation with human papilloma virus 16 and 18. 2014.

9. Guimarães MC, Gonçalves MA, Soares CP, Bettini JS, Duarte RA, Soares EG. Immunohistochemical expression of p16INK4a and bcl-2 according to HPV type and to the progression of cervical squamous intraepithelial lesions. J Histochem Cytochem. 2005;53(4):509-16.
10. Brychtova S, Brychta T, Kotrsova L, Pilka R, Tichy $\mathrm{M}$, Ticha $\mathrm{V}$ et al. Expression of bcl-2 in dysplastic and neoplastic cervical lesions in relation to cell proliferation and HPV infection. Neoplasma. 2000;47:143-7.

11. Nair P, Nair KM, Jayaprakash PG, Radhakrishna MP. Decreased programmed cell death in the uterine cervix associated with high risk human papilloma virus infection. PatholOncol Res. 1999;5:95-103.

12. Takano SM, Hashimura Y, Shoji MY. Okayasu I. The possible role of bcl-2 expression in the progression of tumors of the uterine cervix. Cancer. 1995;76(2):297-303.

13. Grace VM, Shalini JV, lekha TT, Devaraj SN, Devaraj H. co-overexpression of p53 and bcl-2 proteins in HPV-induced squamous cell carcinoma of the uterine cervix. Gynecol Oncol. 2003;91:51-8.

Cite this article as: Kamaraddi $\mathrm{S}$, Nayak AU, Honnappa S, Swarup A. Expression of Bcl-2 marker in premalignant lesions of cervical cancer. Int $\mathbf{J}$ Reprod Contracept Obstet Gynecol 2016;5:965-9. 